\title{
ANALISIS KINERJA PEGAWAI PADA DINAS KEPENDUDUKAN DAN PENCATATAN SIPIL PEMERINTAH KABUPATEN TANGGAMUS
}

\author{
Helmita ${ }^{1}$, Suryani Virginia ${ }^{2}$ \\ Fakultas Ekonomi \& Bisnis, Prodi D3 Akuntansi, Universitas Mitra Indonesia \\ E-mail : mitahelmita@gmail.com ${ }^{1}$, suryanivirginia35@gmail.com²
}

\section{ABSTRACT}

This research took an object at the Population and Civil Registration Office of the Tanggamus Regency as the executor of the implementation of population administration. Problems that occur at this time where the discipline of employees is still not optimal; in addition to competency factors and motivation, other factors that influence employee performance are work discipline.

The population in this study was 83 employees. The results of the study can be concluded that competence, motivation and discipline partially or simultaneously have a significant influence on employee performance. The coefficient of determination ( $R 2)$ is 0.889 . This means that the variables of competence, motivation, and discipline explain the effect on employee performance by $88.9 \%$. Competence, motivation and discipline have influence both partially and simultaneously on the performance of employees at the Population and Civil Registration Office of the Tanggamus Regency.

Keywords: Competence, Motivation, Discipline, Performance

\section{PENDAHULUAN}

\subsection{Latar Belakang}

Salah satu faktor yang mempengaruhi kinerja pegawai, yaitu kompetensi pegawai. (Moeheriono, 2009) mengatakan kompetensi menyangkut kemampuan dasar seseorang untuk melakukan pekerjaan. Faktor lain yang mempengaruhi kinerja adalah Motivasi Kerja. Motivasi kerja merupakan faktor yang dapat mempengaruhi kinerja Pegawai, Motivasi kerja merupakan salah satu aspek penting oleh sumber daya manusia dalam melakukan suatu pekerjaan agar timbul suatu semangat atau kegairahan dalam bekerja. Setiap pegawai memiliki perbedaan motivasi kerja pada dirinya dalam bekerja ada yang menginginkan suatu penghargaan dimana ia bekerja dan rasa puas dalam mengerjakan suatu pekerjaan yang hanya bisa dirasakan oleh dirinya sendiri.

Selain faktor kompetensi dan motivasi faktor lain yang berpengaruh terhadap kinerja pegawai adalah disiplin karena disiplin mampu mempengaruhi kinerja pegawai. Kedisiplinan merupakan fungsi operatif MSDM yang terpenting karena semakin baik disiplin pegawai, maka semakin tinggi prestasi kerja yang dapat dicapainya. Tanpa disiplin kerja yang baik, sulit bagi instansi tersebut untuk mencapai hasil kerja yang optimal (Narmono, 2012).

Penelitian ini mengambil obyek pada Dinas Kependudukan dan Pencatatan Sipil Pemerintah Kabupaten (Pemkab) Tanggamus sebagai penyelenggara pelaksanaan administrasi kependudukan di Kabupaten Tanggamus dibentuk berdasarkan Peraturan Daerah Kabupaten Tanggamus Nomor 24 Tahun 2013 Tentang Administrasi Kependudukan, yaitu rangkaian kegiatan penataan dan penerbitan dalam penerbitan dokumen pada data kependudukan melalui pendaftaran penduduk.

Fenomena atau masalah yang terjadi pada saat ini dimana kedisiplinan pegawai masih kurang maksimal, banyaknya keterangan pegawai yang ijin tidak masuk kerja dengan berbagai alasan. 
Tabel 1.

Rekap Absen Harian Dinas Kependudukan Dan Pencatatan Sipil Pemkab Tanggamus.

\begin{tabular}{ccccccccc}
\hline \multirow{2}{*}{ No } & \multirow{2}{*}{ Bulan } & $\begin{array}{c}\text { Jumlah Wajib Hadir } \\
\text { Perbulan }\end{array}$ & \multicolumn{8}{c}{ Jumlah Hadir } \\
\cline { 4 - 8 } & & 1577 & Alpa & Izin & Sakit & DL & Cuti & Hadir \\
\hline 1 & Februari & 1743 & 47 & 121 & 21 & 29 & - & 1369 \\
2 & Maret & 1743 & 38 & 132 & 27 & 271 & - & 1271 \\
3 & April & 1660 & 38 & 155 & - & 34 & - & 1433 \\
4 & Mei & 996 & 24 & 57 & & 10 & 12 & 893 \\
5 & Juni & &
\end{tabular}

Sumber : Dinas kependudukan Dan Pencatatan Sipil Kabupaten Tanggamus, 2018

Maka disimpulkan bahwa berkaitan kehadiran pegawai Dinas Kependudukan dan pencatatan Sipil Kabupaten tanggamus secara umum terkesan renda dan kurangnya kedisiplinan.

\subsection{Perumusan Masalah}

1. Bagaimana pengaruh kompetensi terhadap kinerja pegawai Dinas Kependudukan dan pencatatan sipil Pemkab Tanggamus?

2. Bagaimana pengaruh motivasi terhadap kinerja pegawai Dinas Kependudukan dan pencatatan sipil Pemkab Tanggamus?

3. Bagaimana pengaruh disiplin terhadap kinerja pegawai Dinas Kependudukan dan pencatatan sipil Pemkab Tanggamus?

4. Bagaimana pengaruh kompetensi, motivasi, dan disiplin secara simultan terhadap kinerja pegawai Dinas Kependudukan dan Pencatatan Sipil Pemkab Tanggamus?

\subsection{Tujuan Penelitian}

1. Untuk mengukur besarnya pengaruh kompetensi terhadap kinerja pegawai pada Dinas Kependudukan dan Pencatatan Sipil Kabupaten Tanggamus.

2. Untuk mengukur besarnya pengaruh motivasi terhadap kinerja pegawai pada Dinas Kependudukan dan Pencatatan Sipil Kabupaten Tanggamus.

3. Untuk mengukur besarnya pengaruh disiplin terhadap kinerja pegawai pada Dinas Kependudukan dan Pencatatan Sipil Kabupaten Tanggamus.

4. Untuk mengukur besarnya pengaruh kompetensi, motivasi, dan disiplin secara simultan terhadap kinerja pegawai pada Dinas Kependudukan dan Pencatatan Sipil Kabupaten Tanggamus.

\section{TINJAUAN PUSTAKA}

\subsection{Kompetensi}

Menurut Moeheriono (2010) pengertian dan arti komopetensi yaitu karakteristik yang mendasari seseorang berkaitan dengan efektifitas kinerja individu dalam pekerjaannya atau karakteristik dasar individu yang memiliki hubungan kausal atau sebagai sebab akibat dengan kreteria yang dijadikan acuan, efektif atau berkinerja prima atau superior ditempat kerja atau pada situasi tertentu. Menurut Wibowo (2012), pengertian Kompetensi merupakan kemampuan melaksanakan pekerjaan atau tugas yang didasari ketrampilan maupun pengetahuan dan didukung oleh sikap kerja yang ditetapkan oleh pekerjaan. Kompetensi menunjukan pengetahuan, ketrampilan dan sikap tertentu dari suatu profesi dalam ciri keahlian tertentu, yang menjadi ciri dari seorang profesional.

Kompetensi seseorang dapat dipengaruhi oleh beberapa faktor (Michael Zwel, 2000 dalam Wibowo, 2012) yaitu: a) Keyakinan dan Nilai-nilai; Perilaku seseorang sangat dipengaruhi oleh keyakinannya terhadap dirinya sendiri dan orang lain. b) Keterampilan; seseorang dalam mengerjakan sesuatu akan meningkatkan rasa percaya diri, dan akan menunjukkan bahwa orang tersebut mempunyai kompetensi dalam bidangnya. c) Pengalaman; akan sangat membantu dalam melakukan suatu pekerjaan, karena pengalaman mengajarkan sesuatu dengan nyata dan akan sangat mudah untuk 
mengingatnya. d) Karakteristik kepribadian; bukanlah sesuatu yang tidak dapat dirubah, kepribadian seseorang akan mempengaruhi cara-cara orang tersebut dalam menyelesaikan permasalahan dalam kehidupan ini, dan hal ini akan membuat orang tersebut lebih kompeten. e) Motivasi; dorongan yang membuat seseorang mampu untuk melakukan sesuatu. f) Isu Emosional; Kondisi emosional seseorang akan berpengaruh dalam setiap penampilannya, termasuk dalam penampilan kerjanya. f) Kemampuan Intelektual; Kompetensi dipengaruhi oleh pemikiran intelektual, kognitif, analitis dan kemampuan konseptual. h)Budaya Organisasi; Budaya organisasi berpengaruh pada kompetensi seseorang dalam berbagai kegiatan, karena budaya organisasi mempengaruhi kinerja, hubungan antar pegawai, motivasi kerja dan kesemuanya itu akan berpengaruh pada kompetensi orang tersebut.

\subsection{Motivasi}

Menurut Hasibuan (2010), Motivasi mempersoalkan bagaimana caranya mengarahkan daya dan potensi bawahan, agar mau bekerja sama secara produktif berhasil mencapai dan mewujudkan tujuan yang telah ditentukan. T. Hani Handoko (2010:252) mengatakan bahwa pengertian motivasi adalah sebagai berikut: "Motivasi adalah keadaan dalam pribadi seseorang yang mendorong keinginan individu untuk melakukan kegiatankegiatan tertentu guna mencapai tujuan".

Tujuan Motivasi menurut Malayu S.P Hasibuan (2010:146) : mengatakan bahwa : (1) Meningkatkan moral dan kepuasan kerja karyawan, (2) Meningkatkan produktivitas kerja karyawan, (3) Mempertahankan kestabilan karyawan perusahaan, (4) Meningkatkan kedisiplinan absensi karyawan. (5), Mengefektifkan pengadaan karyawan, (6) Menciptakan suasana dan hubungan kerja yang baik, (7) Meningkatkan loyalitas, kreativitas dan partisipasi karyawan, (8) Meningkatkan tingkat kesejahteraan karyawan, (9) Mempertinggi rasa tanggung jawab karyawan terhadap tugastugasnya, (10) Meningkatkan efisiensi penggunaan alat-alat dan bahan baku.
Malayu S.P Hasibuan (2010:150), Mengatakan bawah jenis-jenis motivasi adalah sebagai berikut:

1) Motivasi Positif; maksudnya manajer memotivasi (merangsang) bawahan dengan memberikan hadiah kepada mereka yang berprestasi di atas prestasi standar. Dengan motivasi positif, semangat kerja bawahan akanmeningkat karena umumnya manusia senang menerima yang baik-baik saja.

2) Motivasi Negatif; maksudnya manajer memotivasi bawahan dengan standar mereka akan mendapat hukuman. Dengan motivasi negatif ini semangat bekerja bawahan dalam jangka waktu pendek akan meningkat karena mereka takut dihukum, tetapi untuk jangka waktu panjang dapat berakibat kurang baik. Menurut Malayu S. P Hasibuan (2010:149), ada dua metode motivasi, yaitu:

a. Motivasi Langsung (Direct Motivation); adalah motivasi (materiil dan nonmateriil) yang diberikan secara langsung kepada setiap individu untuk memenuhi kebutuhan serta kepuasannya. Jadi sifatnya khusus, seperti pujian, penghargaan, tunjangan hari raya, dan sebagainya.

b. Motivasi Tak Langsung (Indirect Motivation); adalah motivasi yang diberikan hanya merupakan fasilitasfasilitas yang mendukung serta menunjang gairah kerja, sehingga lebih bersemangat dalam bekerja. Misalnya, mesin-mesin yang baik, ruang kerja yang nyaman, kursi yang empuk, dan sebagainya.

\subsection{Disiplin}

Menurut Mangkunegara (2013), disiplin kerja diartikan sebagai pelaksanaan manajemen untuk memperteguh pedomanpedoman organisasi. Menurut Simamora dalam Sinambela (2012:243) tujuan utama tindakan pendisiplinan adalah memastikan bahwa perilaku-perilaku pegawai konsisten dengan aturan-aturan yang ditetapkan oleh organisasi. 


\subsection{Kinerja Pegawai}

Menurut Hasan (2011) Kinerja diartikan sebagai ukuran tingkat kemampuan pekerja secara individual dalam menghargai hasil kerja dan keikut sertaannya dalam menghasilkan barang dan jasa, sebagai produk yang dihasilkan oleh organisasinya. Penghargaan tersebut dilihat dari kualitas dan kuantitas hasil kerja yang dicapainya dan dapat memberikan keuntungan karena mampu memenuhi keinginan dan kebutuhan masyarakat. Menurut Mangkunegara (2013). Kinerja adalah hasil kerja secara kualitas dan kuantitas yang dicapai oleh seorang pegawai dalam melaksanakan tugasnya sesuai dengan tanggung jawab yang diberikan padanya.

Faktor yang mempengaruhi kinerja menurut Mangkunegara (2013) adalah 1) Faktor Kemampuan, secara psikologis kemampuan pegawai terdiri dari kemampuan potensi (IQ) dan kemampuan realiti (skill). 2) Faktor Motivasi, motivasi terbentuk dari sikap seorang pegawai dalam menghadapi situasi kerja. Motivasi merupakan kondisi yang menggerakkan diri pegawai yang terarah untuk mencapai tujuan organisasi.

\subsection{Hipotesis}

1. Ada pengaruh kompetensi terhadap kinerja pegawai pada Dinas Kependudukan dan Pencatatan Sipil Kabupaten Tanggamus.

2. Ada pengaruh motivasi terhadap kinerja pegawai pada Dinas Kependudukan dan Pencatatan Sipil Kabupaten Tanggamus.

3. Ada pengaruh disiplin terhadap kinerja pegawai pada Dinas Kependudukan dan Pencatatan Sipil Kabupaten Tanggamus.

4. Ada pengaruh kompetensi, motivasi, dan disiplin secara bersama-sama terhadap kinerja pegawai pada Dinas Kependudukan dan Pencatatan Sipil Kabupaten Tanggamus.

\section{METODOLOGI PENELITIAN}

\subsection{Jenis Penelitian}

Penelitian ini adalah penelitian survey dengan pendekatan kuantitatif bersifat kausal dengan menggunakan dua sumber data yaitu primer dan skunder. Penelitian dilakukan di Dinas Kependudukan dan Pencatatan Sipil Kabupaten Tanggamus.

\subsection{Populasi Dan Sampel}

Populasi dalam penelitian ini adalah pegawai di Dinas Kependudukandan Pencatatan Sipil Kabupaten Tanggamus sejumlah 83 Pegawai. Dasar pengambilan sampel seperti yang dikemukakan oleh Arikunto, (2010: 120) apabila populasi kurang dari 100 diambil semua sehingga penelitiannya merupakan penelitian sensus, Jadi sampel dalam penelitian ini sebanyak 83 pegawai pada Dinas kependudukan dan Pencatatan Sipil Kabupaten Tanggamus.

\subsection{Teknik Pengumpulan Data}

Menurut Etta Mamang Sangadji Dan Sopiah (2010:169-171) Metode yang digunakan untuk mengumpulkan data dalam penelitian ini adalah 1) Obsevasi (observation). 2) Kuisioner (Questionnaires); Pengumpulan data penelitian pada kondisi tertentu kemungkinan tidak memerlukan kehadiran peneliti.Pertanyaan peneliti dan responden dapat dikemukakan secara tertulis melalu sesuatu kuisioner. Teknik ini memberikan tanggung jawab kepada responden untuk membaca dan menjawab pertanyaan. 3)Wawancara (interview) merupakan teknik dalam pengumpulan data dalam metode survey yang menggunakan pertanyaan secara lisan kepada subyek peneliti.

\subsection{Teknik Analisis Data}

Dalam penelitian ini, metode analisis data yang digunakan adalah Analisis Regresi Linier Berganda. Analisis regresi linier berganda untuk menghitung besarnya pengaruh secara kuantitatif dari suatu perubahan (variabel $X$ ) terhadap kejadian lainnya (variabel $Y$ ), maka digunakan rumus : $Y$ $=\mathrm{a}+b_{1} x_{1}+b_{2} x_{2}+b_{3} x_{3}+\mathrm{e}$

1. Uji Validitas dan reliabilitas Instrumen, menurut Arikunto (2013: 211) validitas adalah suatu ukuran yang menunjukkan tingkat-tingkat kevalidan suatu instrumen. Instrumen yang valid berarti alat ukur yang 
digunakan untuk mendapatkan data (mengukur) itu valid. harus memiliki kriteria jika $r \geq 0,3$ maka item-item tersebut dinyatakan valid. Menurut Sugiyono (2014:348) "Reliabilitas instrumen yaitu suatu instrumen yang bila digunakan beberapa kali untuk mengukur objek yang sama, maka akan menghasilkan data yang sama". Hasil pengukuran yang memiliki tingkat reliabilitas yang tinggi akan mampu memberikan hasil yang terpercaya.

2. Uji Asumsi Klasik, terdiri dari Uji Normalitas, 2) Uji Heteroskedastisitas, 3) Uji Multikolinearitas, 4) Uji Autokolerasi

3. Uji Hipotesis, pengujian hipotesis pada penelitian ini menggunakan analisis regresi linier berganda. Analisis ini digunakan untuk mengetahui pengaruh beberapa variabelindependen $(X)$ terhadap variabel dependen (Y). Analisis linier berganda dilakukan dengan uji koefisien determinasi,uji $R^{2}$, uji $\mathrm{F}$, dan uji T. Model regresi dalam penelitian ini adalah $Y=a+b_{1} x_{1}+b_{2} x_{2}+b_{3} x_{3}+e$

4. Uji Koefisien Determinasi $\left(R^{2}\right)$ digunakan untuk mengukur seberapa jauh kemampuan model dalam menerangkan variasi variabel dependen (Ghozali:2011).
Dari koefisiensi determinasi ini $(\mathrm{R})$ dapat diperoleh suatu nilai untuk mengukur besarnya sumbangan dari beberapa variabel $X$ terhadap variasi naik turunnya variabel $Y$. Nilai $R 2$ yang kecil berarti kemampuan variabel-variabel independen dalam menjelaskan variabel dependen amat terbatas.

5. Uji Statistik F, apabila nilai $F$ hitung lebih besar daripada $F$ tabel, maka dapat dikatakan bahwa semua variabel independen secara bersama-sama mempengaruhi variabel dependen. Menentukan $\mathrm{F}$ tabel dan $\mathrm{F}$ hitung

6. Uji Statistik $\mathrm{t}$, digunakan dalam penelitian ini untuk menguji variabel bebas secara satu persatu ada atau tidaknya pengaruh terhadap variabel terikat $(\mathrm{Y})$. Jika $\mathrm{t}$ hitung $>\mathrm{t}$ tabel, maka menyatakan bahwa suatu variabel independen secara individual mempengaruhi variabel dependen (Ghozali, 2011).

\section{HASIL PENELITIAN DAN} PEMBAHASAN

\subsection{Uji Validitas Instrumen}

Berdasarkan pengolahan data diperoleh data sebagai berikut :

Tabel 2.

Hasil Uji Variabel Pengaruh Kompetensi (X1)

\begin{tabular}{ccccc}
\hline $\begin{array}{c}\text { Butir } \\
\text { Pernyataan }\end{array}$ & R hitung & R tabel & Kondisi & Kesimpulan \\
\hline Pernyataan 1 & 0,787 & 0,443 & R hitung $>r$ tabel & Valid \\
Pernyataan 2 & 0,826 & 0,443 & R hitung $>r$ tabel & Valid \\
Pernyataan 3 & 0,889 & 0,443 & R hitung $>$ r tabel & Valid \\
Pernyataan 4 & 0,867 & 0,443 & R hitung $>r$ tabel & Valid \\
Pernyataan 5 & 0,909 & 0,443 & R hitung $>r$ tabel & Valid \\
Pernyataan 6 & 0,684 & 0,443 & R hitung $>r$ tabel & Valid \\
\hline
\end{tabular}

Sumber : Data diolah 2018.

Tabel 3.

Hasil Uji Variabel Motivasi (X2)

\begin{tabular}{ccccc}
\hline $\begin{array}{c}\text { Butir } \\
\text { Pernyataan }\end{array}$ & R hitung & R tabel & Kondisi & Kesimpulan \\
\hline Pernyataan 1 & 0,753 & 0,443 & R hitung $>$ r tabel & Valid \\
Pernyataan 2 & 0,841 & 0,443 & R hitung $>$ r tabel & Valid \\
Pernyataan 3 & 0,714 & 0,443 & R hitung $>$ r tabel & Valid
\end{tabular}




\begin{tabular}{lllll} 
Pernyataan 4 & 0,676 & 0,443 & R hitung $>$ r tabel & Valid \\
Pernyataan 5 & 0,742 & 0,443 & R hitung $>$ r tabel & Valid \\
Pernyataan 6 & 0,877 & 0,443 & R hitung $>$ r tabel & Valid \\
\hline
\end{tabular}

Sumber : Data diolah 2018.

Tabel 4.

Hasil Uji Variabel Disiplin (X3)

\begin{tabular}{ccccc}
\hline $\begin{array}{c}\text { Butir } \\
\text { Pernyataan }\end{array}$ & R hitung & R tabel & Kondisi & Kesimpulan \\
\hline Pernyataan 1 & 0,781 & 0,443 & R hitung $>r$ tabel & Valid \\
Pernyataan 2 & 0,862 & 0,443 & R hitung $>r$ tabel & Valid \\
Pernyataan 3 & 0,848 & 0,443 & R hitung $>r$ tabel & Valid \\
Pernyataan 4 & 0,813 & 0,443 & R hitung $>r$ tabel & Valid \\
Pernyataan 5 & 0,871 & 0,443 & R hitung $>r$ tabel & Valid \\
Pernyataan 6 & 0,701 & 0,443 & R hitung $>r$ tabel & Valid \\
\hline
\end{tabular}

Sumber : Data diolah 2018.

Tabel 5.

Hasil Uji Variabel Kinerja Pegawai (Y)

\begin{tabular}{ccccc}
\hline $\begin{array}{c}\text { Butir } \\
\text { Pernyataan }\end{array}$ & R hitung & R tabel & Kondisi & Kesimpulan \\
\hline Pernyataan 1 & 0,776 & 0,443 & R hitung $>r$ tabel & Valid \\
Pernyataan 2 & 0,776 & 0,443 & R hitung $>r$ tabel & Valid \\
Pernyataan 3 & 0,858 & 0,443 & R hitung $>r$ tabel & Valid \\
Pernyataan 4 & 0,858 & 0,443 & R hitung $>r$ tabel & Valid \\
Pernyataan 5 & 0,754 & 0,443 & R hitung $>r$ tabel & Valid \\
Pernyataan 6 & 0,776 & 0,443 & R hitung $>r$ tabel & Valid \\
\hline
\end{tabular}

Sumber : Data diolah 2018.

\subsection{Uji Reabilitas Instrumen}

Tabel 6.

Hasil Uji Reliabilitas

\begin{tabular}{ccc}
\hline Variabel & Alpha & Keterangan \\
\hline Kompetensi $(\mathrm{X} 1)$ & 0,804 & Sangat kuat \\
Motivasi $(\mathrm{X} 2)$ & 0,792 & Kuat \\
Disiplin $(\mathrm{X} 3)$ & 0,797 & Kuat \\
Kinerja pegawai $(\mathrm{Y})$ & 0,792 & Kuat \\
\hline
\end{tabular}

Sumber : Data diolah 2018.

Berdasarkan tabel 5 dikonsultasikan pada daftar interpretasi koefisien $r$, maka dapat diartikan bahwa Pengaruh Kompetensi (X1) dengan nilai r Alpha (Cronbach Alpha) sebesar 0.804 memiliki tingkat reliabilitas yang kuat 


\subsection{Hasil Uji Regresi Linier Berganda}

Tabel 7.

Hasil Regresi Linier Berganda

Coefficients $^{a}$

\begin{tabular}{|c|c|c|c|c|c|}
\hline \multirow[t]{2}{*}{ Model } & \multicolumn{2}{|c|}{$\begin{array}{c}\text { Unstandardized } \\
\text { Coefficients }\end{array}$} & $\begin{array}{l}\text { Standardized } \\
\text { Coefficients }\end{array}$ & \multirow[t]{2}{*}{$\mathrm{t}$} & \multirow[t]{2}{*}{ Sig. } \\
\hline & B & Std. Error & Beta & & \\
\hline (Constant) & -2.341 & 1.318 & & -1.777 & .079 \\
\hline Kompetensi & .457 & .104 & .382 & 4.378 & .000 \\
\hline${ }^{1}$ Motivasi & .404 & .085 & .425 & 4.747 & .000 \\
\hline Disiplin & .274 & .073 & .203 & 3.774 & .000 \\
\hline
\end{tabular}

a. Dependent Variable: kinerja pegawai

Sumber : Data diolah 2018.

Dengan melihat tabel 7, maka disusun persamaan persamaan regresi linear berganda adalah $Y=2,341+0,457(X 1)+0,404(X 2)+$ $0,274(X 3)$.

\subsection{Uji Hipotesis}

\section{a. Uji Koefisien determinasi $\left(R^{2}\right)$}

Koefisien determinasi $\left(R^{2}\right)$ pada intinya mengukur seberapa jauh kemampuan model dalam menerangkan variasi variabel dependenya. Nilai koefisien determinasi yang mendekati satu berarti variabel-variabel independenya menjelaskan hampir semua informasi yang dibutuhkan untuk memprediksi variabel dependen, Ghozali (2011). Kemampuan variabel kompetensi $\left(X_{1}\right)$, Motivasi $\left(X_{2}\right)$, dan Disiplin $\left(X_{3}\right)$ menjelaskan pengaruhnya terhadap kinerja pegawai pada kantor Dinas Kependudukan Dan Pencatatan Sipil Kabupaten Tanggamus (Y) ditunjukkan pada tabel 8 berikut:

Tabel 8.

Hasil R Square

Model Summary

\begin{tabular}{c|c|c|c|c}
\hline Model & $\mathrm{R}$ & R Square & Adjusted R Square & Std. Error of the Estimate \\
\hline 1 & $.943^{\mathrm{a}}$ & .889 & .884 & 1.327 \\
\hline
\end{tabular}

a. Predictors: (Constant), disiplin, kompetensi, motivasi

Sumber : Data diolah 2018.

Hal itu berarti bahwa kemampuan variabel independen, yaitu kompetensi (X1), Motivasi (X2), dan Disiplin (X3) menjelaskan pengaruhnya terhadap kinerja pegawai pada kantor Dinas Kependudukan dan Pencatatan Sipil Kabupaten Tanggamus ( $Y$ ) sebesar 0,889 atau $88,9 \%$ dan sisanya $(1-0,88)=0,12$ atau $12 \%$ dipengaruhi oleh variabel lain yang diteliti.

\section{b. Uji Statistik T (Uji T)}

Untuk menguji pengaruh kompetensi (X1), Motivasi (X2), dan Disiplin (X3) secara parsial (individu) terhadap kinerja pegawai pada kantor Dinas Kependudukan dan Pencatatan Sipil Kabupaten Tanggamus (Y) digunakan uji statistik (Uji t). Uji $t$ juga digunakan untuk mengetahui variabel bebas yang mempunyai pengaruh dominan terhadap variabel terikat dengan mengukur derajat hubungan antara variabel bebas dengan variabel terikat dengan menganggap variabel bebas lainnya bersifat konstan. 
Tabel 10.

Hasil Uji t

Coefficients $^{a}$

\begin{tabular}{|c|c|c|c|c|c|}
\hline \multirow[t]{2}{*}{ Model } & \multicolumn{2}{|c|}{$\begin{array}{l}\text { Unstandardized } \\
\text { Coefficients }\end{array}$} & \multirow{2}{*}{$\begin{array}{c}\text { Standardized } \\
\text { Coefficients }\end{array}$} & \multirow[t]{2}{*}{$t$} & \multirow[t]{2}{*}{ Sig. } \\
\hline & $B$ & Std. Error & & & \\
\hline (Constant) & -2.341 & 1.318 & & -1.777 & .079 \\
\hline${ }_{1}$ Kompetensi & 457 & .104 & 382 & 4.378 & .000 \\
\hline Motivasi & .404 & .085 & .425 & 4.747 & .000 \\
\hline Disiplin & .274 & .073 & .203 & 3.774 & .000 \\
\hline
\end{tabular}

a. Dependent Variable: Kinerja Pegawai

Sumber : Data diolah 2018.

Uji t dilakukan dengan membandingkan $t_{\text {hitung }}$ dengan $t_{\text {tabel }}$ pada tingkat signifikata $=(5 \%: 2)=2,5 \%$ (uji dua sisi) dengan derajat kebebasan $/$ degree of freedom $(\mathrm{df})=\mathrm{n}-\mathrm{k}-1$ (83$3-1)=79$. Dengan pengujian dua sisi (signifikan $=0,025)$ hasil diperoleh melalui rujukan Sugiyono (2010), yaitu $t_{\text {tabel }}$ sebesar 1,990. Hasil pengujian parsial (uji t) masing-masing variabel bebas terhadap variabel terikat adalah sebagai berikut.

1. Pengaruh kompetensi $\left(X_{1}\right)$ terhadap kinerja (Y), Jadi t hitung 4,378 > 1,990, artinya $\mathrm{Ho}$ di tolak dan $\mathrm{H} 1$ di diterima, kesimpulannya terdapat pengaruh antara Kompetensi terhadap Kinerja Pegawai.

2. Pengaruh motivasi $\left(X_{2}\right)$ terhadap kinerja pegawai $(Y)$ diperoleh $t$ hitung untuk variabel Motivasi $\left(X_{2}\right)$ adalah sebesar 4.747 sedangkan untuk $t$ tabel $(\mathrm{dk}=\mathrm{n}$ $\mathrm{k}=83-4=79$ ) adalah sebesar 1,990. Jadi tHitung 4,747> tTabel 1,990, artinya Ho di tolak dan $\mathrm{H} 1$ di terima, kesimpulannya terdapat pengaruh antara disiplin terhadap kinerja pegawai.

3. Pengaruh disiplin $\left(X_{3}\right)$ terhadap Kinerja Pegawai $(Y)$ diperoleh $t$ hitung untuk variabel motivasi (X2) adalah sebesar 4.774 sedangkan untuk tTabel ( $d \mathrm{k}=\mathrm{n}$ $k=83-4=79)$ adalah sebesar 1,990. Jadi thitung 4,774 > t tabel 1,990, artinya Ho di tolak dan $\mathrm{H} 1$ di terima, kesimpulannya terdapat pengaruh antara disiplin terhadap kinerja pegawai.

\section{c. Uji Statistik F (Uji F)}

Hipotesis yang diajukan dalam penelitian ini adalah : kompetensi, motivasi dan disiplin mempunyai pengaruh secara bersamasama terhadap kinerja pegawai pada kantor Dinas Kependudukan dan Pencatatan Sipil Kabupaten Tanggamus. Hasilnya dapat dilihat pada tabel 9 berikut:

Tabel 9.

Hasil Uji F

ANOVAa

\begin{tabular}{lrrrrr}
\hline \multicolumn{1}{c}{ Model } & Sum of Squares & Df & Mean Square & F & Sig. \\
\hline Regression & 1110.098 & 3 & 370.033 & 210.109 & $.000^{\mathrm{b}}$ \\
\cline { 2 - 6 } & 139.131 & 79 & 1.761 & & \\
\hline Residual & 1249.229 & 82 & & & \\
\hline
\end{tabular}

a. Dependent Variable: kinerja pegawai

b. Predictors: (Constant), disiplin, kompetensi, motivasi

Sumber : Data diolah 2018. 
Nilai Fhitung sebesar 210,109. Dengan menggunakan tingkat keyakinan $95 \%, \alpha=5 \%$, df1 (jumlah variabel bebas) $=3$, df2 $(n-k-1)=79$, dengan demikian dapat diketahui Ftabel $=2,72$ Sugiyono (2010). Apabila nilai Fhitung > nilai Ftabel maka Ho ditolak dan $\mathrm{Ha}$ diterima, sebaliknya apabila nilai Fhitung< nilai Ftabel maka Ho diterima dan $\mathrm{Ha}$ ditolak. Dengan demikian dapat diketahui bahwa nilai Fhitung > Ftabel $(210,109>2,72)$. Berdasarkan uji $F$ diatas maka disimpulkan bahwa kompetensi, motivasi dan disiplin secara simultan memiliki pengaruh yang signifikan terhadap kinerja pegawai dan $\mathrm{Ha}$ diterima. Hal ini berarti bahwa kompetensi, motivasi dan disiplin yang dimiliki dari seorang pegawai sangat diperlukan dalam melaksanakan tugas selaku abdi masyarakat dan tentunya dapat meningkatkan produktivitas kinerja pegawai di Dinas Kependudukan dan Pencatatan Sipil Kabupaten Tanggamus.

\section{SIMPULAN DAN SARAN}

\subsection{Simpulan}

Dapat disimpulkan bahwa kompetensi, motivasi dan disiplin secara parsial maupun simultan mempunyai pengaruh yang signifikan terhadap kinerja pegawai pada kantor Dinas Kependudukan dan Pencatatan Sipil Kabupaten Tanggamus. Berdasarkan hasil uji koefisien determinasi $\left(R^{2}\right)$, maka diperoleh nilai koefisien determinasi sebesar 0,889 (88,9\%). Hal ini berarti bahwa variabel kompetensi, motivasi, dan disiplin menjelaskan pengaruhnya terhadap kinerja pegawai pada kantor Dinas Kependudukan dan Pencatatan Sipil Kabupaten Tanggamus sebesar 88,9 \%, sedangkan sisanya $12 \%$ merupakan variabel lain diluar model.

\subsection{Saran}

Agar lebih memperhatikan dan meningkatkan kinerja pegawai Apabila suatu instansi melakukan aktivitas instansi pemerintah dengan kinerja yang kurag baik maka citra instansi akan kurang baik. Apapun pangkat dan golongan, tugas utama dari aparatur negara adalah melayani dan mengayomi masyarakat. Dengan memberikan pelayanan terbaik maka akan memperoleh citra yang baik pula.

\section{DAFTAR PUSTAKA}

A.A. Anwar Prabu Mangkunegara, 2013, Manajemen Sumber Daya Manusia Perusahaan. Bandung: PT. Remaja Rosda Karya.

Arikunto Suharsini, Prosedur Penelitian: Suatu Pendekatan Praktek. Jakarta: Rineka Cipta.2010.

Drs.H.Malayu S.P Hasibuan, 2012, Manajemen Sumber Daya Manusia. Bumi aksara.

Ghozali, Imam. 2011, Aplikasi Analisis Multivariate dengan program SPSS, Edisi ketujuh, Semarang :badan penerbit universitas diponegoro.

Hartati, 2010, Pengaruh motivasi, disiplin kerja dan kompetensi terhadap kinerja Pegawai Dinas Pendidikan Kabupaten Sragen Jurnal Paradigma vol 12, No 01.

Hasan, 2011, Suryani. Jurnal IImu Administrasi. Volume VIII. No. 3. Desember.

Hasibuan. S.P. Malayu, 2010, Organisasi dan Motivasi, PT Bumi Aksara, Jakarta

Jurnal paradigma vol 12, No. 01, Februari - Juli 2014-12.

Marwansyah. 2010., Manajemen Sumber Daya Manusia. Alfabeta:Bandung.

Moeheriono, 2010, Pengukuran Kinerja Berbasis Kompetensi, Bogor, Ghalia Indonesia.

Narmono, P. 2012. Manajemen Sumber Daya Manusia. Edisi Keempat. Jakarta: PT. Gramedia Pustaka Utama.

Notoatmodjo, S. 2010. Metodologi Penelitian, Jakarta : Rineka Cipta.

Peraturan Pemerintah Republik Indonesia Nomor 53 tahun 2010 tentang Disiplin Pegawai Negeri Sipil (PNS), Jakarta.

Santoso, Singgih, 2012. Panduan Lengkap SPSS Versi 20. Jakarta: PT Elex Media Komputindo.

Simamora, Sinambela. 2012, Kedisiplinan Pegawai: Teori, Pengukuran dan Implikasi.Yogyakarta: Graha I.

Sugiyono. 2014, Metode Penelitian Pendidikan Pendekatan Kuantitatif, Kualitatif Dan $R \& D$. Bandung: Alfabeta.

Sugiyono, 2013. 
Sungadji, Etta Mamang danSopiah 2010, Metodologian Penelitian.Yogyakarta: penerbit CV Andi offset.

Sutrisno, Edy. Manajemen Sumber Daya Manusia, Edisi pertama, Jakarta: kencana. 2013.

UU No 23 Telah diubah oleh UU No 24/2013 kementrian dalam negri Republik Indonesia Direktorat Jenderal kependudukan dan Pencatatan Sipil
Wibowo. 2012, Manajemen Kinerja. Jakarta: Raja Grafindo Persada.

http://repository.umy.ac.id/bitstream/handle/123 456789/10498/f.\%20BAB\%20ll.pdf?seq uence $=6$ \&isAllowed $=y$

https://ejournal.unsrat.ac.id/index.php/jurnaleks ekutif/article/viewFile/2678/2231

http://repository.usu.ac.id/bitstream/handle/123 456789/59639/Chapter\%20l.pdf?seque nce

http://disdukcapil.tanggamus.go.id/ 
ISSN 2086-9592 